\title{
PERSEPSI MAHASISWA TENTANG PENGELOLAAN PEMBELAJARAN MATA KULIAH DASAR KEAHLIAN (MKDK)
}

\author{
Neti Karnati
}

\begin{abstract}
This research is intended to get empirical data on elementary school teacher's attitude towards children with special needs in the elementary school, DKI Jakarta. The research was held at the department of PGSD (Elementary School Teacher Education), Setia Budi Campus, School of Education of Jakarta (FIP-UNJ), selected sample randomly. The random sample 105 are elementary school teacher doing undergraduate program in basic education. The result shows that teacher's attitude toward student with special needs have the acceptance limit score for 81.25. This means that any score above the limit score is categorized as positive attitude and score below the limit score is considered as negative attitude. On the cognition aspect, the score is 37.92 meaning teachers have negative attitude towards children with special needs. The score for affection and conation aspect are 26.92 meaning negative attitude too. For the theoretical aspect, the maximum score is 150 whereas the minimum score is 50. Research analysis shows that the maximum empirical score is 146 with the minimum of 88. The average score is 120 meaning that elementary school teachers have positive attitude towards children with special needs.
\end{abstract}

Keywords: attitude, instructional management, children with special needs.

\section{PENDAHULUAN}

\section{Latar Belakang Masalah}

Sejak dikeluarkannya Keputusan Presiden (Keppres) 093/1999 Tanggal 4 Agustus Tahun 1999, Institut Keguruan dan Ilmu Pendidikan (IKIP) Jakarta telah berubah menjadi Universitas Negeri Jakarta (UNJ). Dengan perubahan tersebut maka berubah juga visi, misi, dan tujuannya. Tujuan UNJ yang diuraikan dalam buku pedoman akademik (2004) adalah sebagai berikut.

1. Mendalami dan menyebarluaskan ilmu pendidikan dan nonkependidikan yang menjadi komponen pokok penyelenggaraan pendidikan, penelitian, dan pengabdian kepada masyarakat.

2. Menghasilkan tenaga akademik dan atau profesional pada berbagai jenjang dan jenis yang memiliki kemampuan dalam menunjang usaha pengembangan dan pemberdayaan Sumber Daya Manusia (SDM) berbagai jenjang, jenis, dan jalur.

3. Menghasilkan tenaga kependidikan dan nonkependidikan yang bermutu, berkemampuan akademik dan atau profesional dibidangnya.

4. Memfasilitasi dan melaksanakan program pendidikan dalam jabatan (in service training) untuk jabatan tenaga kependidikan dan tenaga penunjang akademik di dalam maupun di luar negeri.

5. Mengabdikan ilmu, teknologi, dan atau seni untuk kepentingan dan pemenuhan kebutuhan masyarakat.
6. Memfasilitasi pelayanan teknologi, pengelolaan, dan sistem informasi bagi civitas akademika UNJ dan masyarakat luas.

7. Menjalin kemitraan dalam upaya pemberdayaan dan peningkatan kapasitas daerah.

Kebijakan untuk mencapai visi, misi, dan tujuan didasarkan pada prinsip partisipatif, akuntabilitas, transparansi, pemanfaatan teknologi yang sesuai, orientasi pada realitas kebutuhan dan dunia kerja, integral atau keterpaduan, dan keseimbangan antara program kependidikan dan nonkependidikan.

Untuk mewujudkan tujuan UNJ banyak faktor yang dapat mempengaruhi, yaitu SDM yang terdiri dari para tenaga edukatif dan tenaga administratif yang berkualitas, sarana dan prasarana akademik, mahasiswa, keuangan, kurikulum, lingkungan masyarakat, serta pengelolaan terhadap berbagai komponen yang ada pada UNJ, seperti pengelolaan pembelajaran atau akademik.

UNJ sebagai salah satu jenis perguruan tinggi yang ada di Indonesia selalu mengikuti berbagai kebijakan dari pemerintah. Salah satunya adalah kebijakan Keputusan Menteri (Kepmen) No. 232/U/ 2000 Tentang Pedoman Penyusunan Kurikulum Pendidikan Tinggi dan Penilaian Hasil Belajar Mahasiswa. Kepmen tersebut dibuat sebagai salah satu upaya pemerintah dalam meningkatkan kualitas perguruan tinggi yang menjelaskan tentang seperangkat rencana dan pengaturan mengenai isi maupun bahan kajian dan pelajaran serta cara 
penyampaian dan penilaian yang digunakan, serta pembagian rumpun kelompok mata kuliah. Rumpun mata kuliah yang tercantum dalam Kepmen No. 232/ U/2000 meliputi: (1) Mata kuliah Pengembangan Kepribadian (MPK), (2) Mata kuliah Keilmuan dan Keterampilan (MKK), (3) Mata kuliah Keahlian Berkarya, (4) Mata kuliah Perilaku Berkarya (MPB), dan (5) Mata kuliah Berkehidupan Bermasyarakat (MBB). Lebih lanjut dijelaskan tentang kurikulum pendidikan tinggi yang terdiri dari kurikulum inti dan kurikulum institusional.

Kurikulum inti merupakan kelompok bahan kajian dan pelajaran yang harus terdapat dalam suatu program studi (prodi), dirumuskan dalam kurikulum yang berlaku secara nasional dan mencakup isi, yaitu (1) MPK, (2) MKK, (3) MKB, (4) MPB, dan (5) MBB. Kurikulum institusional adalah sejumlah bahan kajian dan pelajaran yang merupakan bagian dari kurikulum pendidikan tinggi, terdiri dari tambahan dari kelompok ilmu dalam kurikulum inti yang disusun dengan memperhatikan keadaan dan kebutuhan lingkungan, serta ciri khas perguruan tinggi yang bersangkutan. Bobot muatan isi dalam kurikulum inti berkisar $40 \%$ $80 \%$. Untuk mewujudkan tujuannya, UNJ saat ini menyelenggarakan dua jenis program, yaitu program kependidikan dan nonkependidikan. Program kependidikan diadakan pada semua prodi yang ada di UNJ sebagai kelanjutan pembinaan dari program IKIP Jakarta. Dengan harapan pada tahun 2010 UNJ menjadi institusi yang memiliki keunggulan di bidang kependidikan. Dengan demikian, UNJ telah memiliki kurikulum kependidikan dan kurikulum nonkependidikan. Kurikulum kependidikan yang ditetapkan mengacu kepada kurikulum nasional sesuai dengan Kepmen dikbud RI No. 021/U/1995 Tanggal 25 Juli 1995. Struktur kurikulum kependidikan S1 mencakup: (1) Mata Kuliah Umum (MKU), (2) Mata Kuliah Dasar Kependidikan (MKDK), dan (3) Mata Kuliah Keahlian (MKK). MKU ditempuh sebanyak 12 SKS, MKDK sebanyak 12 SKS sedangkan MKK sesuai dengan bidang studi masing-masing maksimal jumlah seluruhnya 136 SKS.

Salah satu rumpun mata kuliah program kependidikan di UNJ, yaitu MKDK dengan pihak universitas sebagai penanggung jawab yang terdiri dari: (1) Pengantar Ilmu Pendidikan dengan bobot empat SKS, (2) Psikologi Perkembangan dengan bobot dua SKS, (3) Teori Belajar dan Pembelajaran dengan bobot empat SKS, dan (4) Profesi Kependidikan dengan bobot dua SKS. Mengingat betapa pentingnya MKDK dalam menyiapkan para calon tenaga kependidikan yang profesional maka sudah seharusnya MKDK bagi program S1 kependidikan ini dikelola semaksimal mungkin baik oleh tingkat UNJ maupun oleh dosen yang memberi kuliah MKDK. MKDK di UNJ sampai saat ini dikelola di bawah tanggung jawab Fakultas Ilmu Pendidikan (FIP) melalui kerja sama dengan koordinator MKDK UNJ. Proses perencanaan, pelaksanaaan perkuliahan, dan evaluasi perkuliahan MKDK menjadi tugas dan tanggung jawab FIP UNJ. Para pembelajar atau dosen yang mengampu mata kuliah ini dibebankan kepada seluruh dosen FIP UNJ. Para dosen FIP dari berbagai jurusan dan prodi yang ada di FIP harus mampu melakukan pengelolaan pembelajaran dalam MKDK secara profesional di samping mereka juga harus mengampu beberapa mata kuliah pada prodi masing-masing.

Pada kenyataannya menurut informasi dari Koordinator MKDK UNJ masih ditemukan dosendosen FIP yang tidak bersedia untuk membelajarkan MKDK walaupun sudah terjadwal dalam jadwal terpadu. Di samping itu, walaupun mereka bersedia seringkali tidak melaksanakannya dengan sungguhsungguh. Hal ini dapat terlihat dari kehadiran yang masih kurang dan terlambat atau sistem pembelajaran yang terkesan konvensional. Selain ditemukannya kendala pada dosen masih juga ada kendala pada beberapa mahasiswa peserta MKDK yang terkesan mengikuti perkuliahan MKDK hanya sekedar formalitas. Hal ini terbukti masih banyak mahasiswa yang hadir masih terlambat, enggan membeli buku sumber perkuliahan, tidak mengerjakan tugas dari dosen dengan baik, dan kurang aktif dalam belajar di kelas. Kendala lain dapat dilihat juga dari pengaturan fasilitas belajar yang masih sangat kurang seperti ruang kuliah yang berisik, kotor, panas, media belajar Over Head Projector (OHP) yang kurang memadai baik kuantitasnya dan kualitasnya, serta meja dosen dan kursi mahasiswa yang kadang-kadang belum tertata rapi dan kurang. Selain itu, menurut dosen dan mahasiswa, pihak koordinator serta staf yang masih kurang baik, misalnya ruangan yang sempit dan seringnya ruang sekretariat MKDK yang kosong.

Dengan melihat beberapa kendala di atas maka kami tertarik untuk meneliti persepsi mahasiswa tentang pengelolaan pembelajaran dalam perkuliahan MKDK bagi mahasiswa S1 program kependidikan di UNJ. Pengelolaan pembelajaran meliputi kegiatan perencanaan perkuliahan, pelaksanaan perkuliahan, dan evaluasi hasil belajar MKDK.

\section{Identifikasi Masalah}

Berdasarkan uraian penjelasan pada latar belakang maka dapat diidentifikasikan masalahmasalah sebagai berikut. 
1. Apakah MKDK di UNJ bagi mahasiswa program kependidikan masih diperlukan?

2. Siapakah yang harus bertanggung jawab terhadap perkuliahan MKDK?

3. Mengapa para dosen MKDK bagi program kependidikan di UNJ belum memiliki motivasi yang tinggi dalam melaksanakan MKDK?

4. Bagaimana sistem perencanaan pembelajaran MKDK bagi program kependidikan di UNJ?

5. Bagaimana sistem pelaksanaan pembelajaran MKDK bagi program kependidikan di UNJ?

6. Bagaimanakah sistem evaluasi pembelajaran MKDK bagi program kependidikan di UNJ?

\section{Pembatasan Masalah}

Berdasarkan keterbatasan kemampuan peneliti,

baik waktu, tenaga, dan biaya maka tidak semua masalah pengelolaan pembelajaran MKDK diteliti. Penelitian ini hanya dibatasi pada pengelolaan pembelajaran MKDK bagi mahasiswa program kependidikan S1 di UNJ pada semester 086, JanuariJuni 2007. Pengelolaan pembelajaran MKDK adalah proses perencanaan, pelaksanaan, dan evaluasi pembelajaran MKDK bagi mahasiswa program kependidikan di UNJ. Pengelola pembelajaran MKDK yang dimaksud adalah koordinator MKDK dan dosen FIP yang mengampu MKDK, meliputi mata kuliah di antaranya: (1) Pengantar Ilmu Pendidikan, (2) Psikologi Perkembangan, (3) Teori Belajar dan Pembelajaran, dan (4) Profesi Kependidikan.

\section{Perumusan Masalah}

Berdasarkan latar belakang masalah, identifikasi masalah, dan pembatasan masalah maka dapat dirumuskan masalah penelitian ialah "Bagaimanakah persepsi mahasiswa tentang pengelolaan pembelajaran mata kuliah dasar keahlian (MKDK) bagi mahasiswa program kependidikan di UNJ pada semester 086 tahun 2007?"

\section{Tujuan Penelitian}

Penelitian ini secara umum bertujuan untuk mengungkapkan secara empiris bagaimanakah persepsi mahasiswa tentang pengelolaan pembelajaran yang meliputi kegiatan perencanaan, pelaksanaan, dan evaluasi pembelajaran oleh dosen dalam MKDK bagi mahasiswa program kependidikan di UNJ?

Tujuan secara operasional dari penelitian ini adalah sebagai berikut.

1. Bagaimanakah persepsi mahasiswa tentang sistem perencanaan pembelajaran MKDK bagi program kependidikan di UNJ?

2. Bagaimanakah persepsi mahasiswa tantang sistem pelaksanaan pembelajaran MKDK bagi program kependidikan di UNJ?
3. Bagaimanakah persepsi mahasiswa tentang sistem evaluasi pembelajaran MKDK bagi program kependidikan di UNJ?

4. Apakah faktor-faktor yang menghambat dan mendukung pengelolaan pembelajaran MKDK bagi program kependidikan di UNJ?

\section{Manfaat Penelitian}

Penelitian ini diharapkan dapat digunakan sebagai bahan masukan bagi para manajer perkuliahan MKDK bagi program kependidikan di UNJ seperti bagi dosen MKDK, koordinator MKDK, pimpinan FIP, Rektor UNJ, dan Pembantu Rektor (PR) I UNJ dalam rangka mengambil kebijakan pengembangan MKDK program kependidikan sehingga mampu memberikan layanan MKDK untuk memenuhi kebutuhan pembekalan kemampuan dasar dan keahlian para mahasiswa program S1 kependidikan.

\section{KAJIAN TEORETIS}

\section{Hakikat Persepsi}

1. Pengertian persepsi

Rivai (2004) mengatakan bahwa persepsi adalah suatu proses yang ditempuh individu untuk mengorganisasikan dan menafsirkan kesan-kesan indra mereka agar memberikan makna bagi lingkungan mereka.

Individu memberikan pandangan atau pendapat dari apa yang dia rasa, dengar, raba, cium, dan lihat mengenai objek atau benda yang dia perhatikan. Menurut Thoha (2003) persepsi pada hakikatnya adalah proses kognitif yang dialami oleh setiap orang di dalam memahami informasi tentang lingkungannya, baik lewat penglihatan, pendengaran, penghayatan, perasaan, dan penciuman.

Persepsi adalah suatu proses yang menggabungkan dan mengorganisasikan data-data indra kita (pengindraan) untuk dikembangkan sedemikian rupa sehingga kita dapat menyadari sekeliling kita termasuk sadar akan diri kita sendiri.

Melalui persepsi kita dapat menggambarkan sekeliling kita menggunakan panca indra yang ada pada diri kita yang belum tentu sama dengan apa yang dipersepsikan orang lain.

a. Faktor-faktor yang mempengaruhi persepsi

Persepsi tidak terjadi begitu saja ada hal-hal lain yang membuat seseorang mempersepsikan suatu objek atau benda. Rahmat (1999) mengelompokkan faktor-faktor yang mempengaruhi persepsi ke dalam beberapa kelompok, 
yaitu faktor personal, faktor situasional, dan faktor perhatian.

Faktor personal adalah faktor-faktor yang timbul dari dalam diri individu itu sendiri berupa pengalaman, motivasi, dan kepribadian. Faktor situasional adalah faktor yang ditimbulkan oleh keadaan pada suatu lingkungan di mana orang atau organisme berinteraksi. Faktor perhatian terjadi apabila diri individu mengkonsentrasikan dari salah satu alat indra dan mengenyampingkan masukan-masukan dari alat indra lainnya. Perhatian yang terjadi bukanlah perhatian sekilas melainkan membutuhkan konsentrasi pada suatu objek atau benda.

Menurut Walgito (2002) stimulus atau rangsangan merupakan salah satu faktor yang berperan dalam persepsi. Selain itu, ada juga faktor lainnya seperti objek atau benda yang dipersepsikan, alat indra atau saraf dan pusat susunan saraf, serta perhatian.

b. Hambatan-hambatan dalam persepsi

Ketika menyampaikan suatu persepsi belum tentu apa yang kita persepsikan sama dengan yang orang lain persepsikan. Hal ini bisa disebabkan adanya hal-hal yang menghambat persepsi seseorang. Menurut Gunawan (1989) hambatan dalam persepsi dapat digolongkan menjadi tiga kategori, yakni hambatan teknis, hambatan semantik (peristilahan), dan hambatan manusiawi.

Hambatan teknis disebabkan oleh karena adanya keterbatasan fasilitas dan peralatan komunikasi yang sebagian besar disebabkan oleh kesalahan mekanis, gangguan fisik, gagalnya penerapan teknologi, dan faktor ruang serta waktu yang dapat secara jelas dilokalisir dalam penerimaan media.

Hambatan semantik dapat menjadi hambatan yang utama dalam proses penyampaian pengertian atau ide secara efektif. Banyak proses komunikasi yang terjadi dalam bentuk bahasa, akan tetapi kata yang diucapkan seseorang mungkin akan berbeda bagi orang lain jika dalam keadaan konteks yang berbeda. Hambatan semacam ini sering kali terjadi, misalnya ketika seseorang melihat suatu benda, belum tentu apa yang akan dilihat orang tersebut sama dengan pandangan orang lain.

Hambatan manusiawi adalah hambatan yang berasal dari manusia itu sendiri. Hambatan ini yang paling serius dalam segala bentuk komunikasi. Hal ini dapat terjadi karena faktor emosi, prasangka pribadi, kecakapan, dan kemampuan panca indra. Misalnya, ketika seseorang melihat orang lain membantu korban bencana alam ada yang mengatakan orang tersebut memang dengan ikhlas karena panggilan jiwa ingin menolong atau ada juga yang mengatakan ingin mencari nama atau ada kepentingankepentingan tertentu.

c. Kekeliruan dan kegagalan persepsi

Beberapa bentuk kekeliruan dan kegagalan persepsi adalah kesalahan atribusi, efek halo (halo effect), stereotip, prasangka, dan gegar budaya. Atribusi adalah proses internal dalam diri kita untuk memahami penyebab perilaku orang lain. Kesalahan atribusi bisa terjadi ketika kita salah menaksir makna pesan atau maksud perilaku si pembicara. Salah satu sumber kesalahan atribusi adalah pesan yang tidak utuh atau tidak lengkap sehingga kita berusaha menafsirkan pesan tersebut dengan menafsirkan sendiri kekurangannya. Kesalahan persepsi yang disebut efek halo merujuk pada fakta bahwa begitu kita membentuk suatu kesan menyeluruh mengenai seseorang, kesan yang menyeluruh ini cenderung menimbulkan efek yang kuat atas penilaian kita akan sifat-sifatnya yang spesifik.

Kesulitan komunikasi akan muncul dari penstereotipan (stereo-typing), yakni menggeneralisasikan orang-orang berdasarkan sedikit informasi dan membentuk asumsi mengenai mereka berdasarkan keanggotaan mereka dalam suatu kelompok. Prasangka adalah suatu kekeliruan persepsi terhadap orang yang berbeda. Orang yang berprasangka cenderung mengabaikan informasi yang tidak sesuai dengan generalisasi mereka yang keliru dan kaku. Menurut Oberg (1960), gegar budaya ditimbulkan oleh kecemasan karena hilangnya tanda-tanda yang sudah dikenal dan simbol-simbol hubungan sosial. Dengan mengetahui beberapa bentuk kekeliruan dan kegagalan persepsi tersebut maka setiap individu dapat lebih cermat dalam memandang orang lain, tidak hanya berdasarkan yang terlihat oleh indra penglihatan saja.

\section{Hakikat Pengelolaan Pembelajaran}

1. Pengertian pengelolaan pembelajaran

Pengelolaan dapat dikatakan sebagai seni dan ilmu. Pengelolaan sebagai seni pada hakikatnya timbul bersama-sama dengan dimulainya peradaban manusia. Sejak manusia berbudaya, mengembangkan akal pikirannya, mulai timbul administrasi, dan pengelolaan. Pengelolaan diartikan sebagai 
pengelolaan kegiatan dengan pemanfaatan segala sumber daya, baik manusia maupun nonmanusia untuk mencapai tujuan yang telah direncanakan. Untuk mendukung pernyataan di atas, berikut ini disajikan definisi tentang pengelolaan dari beberapa kalangan.

Terry dan Rue (1985) menyatakan “Management is a distinct process consisting of planning, organizing, actuating, and controlling, performed to determine and accomplish stated objectives by use of human beings and other resources". (Pengelolaan adalah suatu proses yang terdiri dari perencanaan, pengorganisasian, pengarahan, dan pengawasan yang dilakukan untuk menentukan dan mencapai tujuan-tujuan yang telah ditentukan dengan menggunakan orang-orang dan sumber daya lainnya). Di sini Terry dan Rue (1985) menekankan dalam pengelolaan tedapat pemisahan dan urutan kegiatan dalam kegiatan. Menurut Gagne dan Briggs (1979), pembelajaran didefinisikan sebagai suatu rangkaian yang mempengaruhi pelajar atau siswa sedemikian rupa sehingga proses belajarnya dapat berlangsung dengan mudah. Dengan demikian, dapat diartikan bahwa pengelolaan pembelajaran adalah suatu proses pengaturan terhadap kegiatan pembelajaran yang meliputi kegiatan perencanaan, pelaksanaan, dan penilaian belajar membelajarkan dalam rangka mencapai tujuan.

2. Fungsi-fungsi pengelolaan pembelajaran

\section{a. Perencanaan pembelajaran}

Untuk mencapai tujuan yang diharapkan, seorang dosen memerlukan suatu perencanaan demikian juga dalam proses belajar membelajarkan. Perencanaan memudahkan kita untuk mencapai tujuan pembelajaran yang diharapkan. Selain itu, dengan perencanaan juga dapat kita ketahui halhal yang tidak mungkin sesuai dengan tujuan.

Untuk membuat suatu perencanaan pembelajaran para ahli pendidikan dan pembelajaran berkecenderungan menggunakan pendekatan sistem. Menurut Sunarya (1996), "Sistem adalah sekelompok bagian yang bekerja sama secara keseluruhan berdasarkan suatu tujuan bersama." Adapun pendekatan sistem menurut Johnson, Kast, dan Rosenzweig (1973) adalah "Cara berpikir untuk mengatur tugas, melalui suatu kerangka yang melukiskan faktor-faktor lingkungan internal dan eksternal sehingga merupakan suatu keseluruhan secara terpadu."

Pendekatan sistem pada pembelajaran bertujuan agar kita semua dapat mengerti masalah pembelajaran sebagai keseluruhan secara tuntas dan dapat mendalami pula apa bagian-bagiannya.
Diharapkan juga dengan pendekatan sistem pada pembelajaran, kita dapat memahami pula cara bagaimana masing-masing bagian itu saling berinteraksi, saling berfungsi, dan saling bergantung di dalam suatu sistem untuk mencapai tujuan tertentu.

Menurut Roestiyah (1994), sistem pembelajaran adalah suatu keseluruhan dari sejumlah komponen-komponen pembelajaran yang berfungsi saling bergantung dan berinteraksi di dalam proses mencapai tujuan pembelajaran yang telah dirumuskan

Seperti yang telah diuraikan di muka proses pembelajaran bukan merupakan suatu keadaan yang terjadi secara kebetulan tetapi keadaan yang telah didesain (dipersiapkan dan direncanakan), diatur, diawasi, serta diarahkan dengan mempertimbangkan beberapa kemungkinan yang mempengaruhi tingkah laku siswa karena guru memegang peran yang penting. Untuk dapat berfungsi sebagaimana yang diharapkan, guru memerlukan suatu pedoman dasar dalam menyelenggarakan proses pembelajaran:

1) komponen-komponen pokok yang membentuk dan memberi ciri-ciri yang khas suatu proses pembelajaran;

2) faktor-faktor utama yang paling banyak mempengaruhi penyelenggaraan proses tersebut; dan

3) contoh-contoh suatu model pelaksanaan proses pembelajaran sehingga guru dapat menciptakan suatu proses yang sesuai dengan situasi dan kebutuhan, serta tujuan tertentu.

Pada waktu seorang dosen mendesain pembelajaran maka perlu memikirkan komponenkomponen dasar tertentu yang akan menjadi pola dari proses desain itu. Komponen-komponen tersebut antara lain tujuan pembelajaran, materi pelajaran, pendidikan, sistem penyajian, murid, guru sumber belajar, pengelolaan interaksi belajar, evaluasi, dan pengembangan.

Beberapa kemampuan merencanakan pembelajaran yang harus dikuasai dosen adalah sebagai berikut.

1) Merencanakan pengelolaan kegiatan belajar membelajarkan.

2) Merencanakan pengorganisasian bahan pembelajaran.

3) Merencanakan pengelolaan kelas.

4) Merencanakan penggunaan alat dan metode pembelajaran.

5) Merencanakan penilaian prestasi murid untuk kepentingan pembelajaran. 
Menurut Julitriarsa dan Suprihanto (1998), ada beberapa manfaat perencanaan pembelajaran sebagai berikut.

1) Sebagai alat pengawasan dalam pengendalian pelaksanaan organisasi.

2) Untuk memilih dan menentukan prioritas dari beberapa alternatif yang ada.

3) Untuk mengarahkan dan menentukan pelaksanaan kegiatan sehingga tertib dan teratur menuju tujuan yang telah ditentukan sebelumnya.

4) Untuk menghadapi dan mengurangi ketidakpastian di masa yang akan datang.

5) Perencanaan yang baik mendorong tercapainya tujuan.

b. Pelaksanaan pembelajaran

Tugas seorang dosen ialah membelajarkan, prosesnya dimulai di mana dosen harus membimbing anak belajar dengan menyediakan situasi kondisi yang tepat agar potensi anak dapat berkembang semaksimal mungkin. Ada tiga tahapan membelajarkan bagi guru dalam pelaksanaan kegiatan belajar membelajarkan, yaitu kegiatan pembukaan, kegiatan inti, dan kegiatan penutup. Kegiatan pembukaan, sebelum proses belajar membelajarkan dimulai, seorang dosen sebaiknya mengenal kemampuan awal mahasiswanya atau disebut dengan istilah entering behavior. Dalam pembuatan persiapan harian sering dikenal dengan istilah apersepsi. Kegiatan pembukaan meliputi kegiatan pengelolaan kelas yaitu mengarahkan siswa ke dalam situasi belajar membelajarkan; dan kegiatan apersepsi, dapat dilakukan dengan mengajukan pertanyaan tentang konsep, prinsip, atau kecakapan lain yang telah dimiliki siswa yang berhubungan dengan bahan yang dipelajari saat itu.

Kegiatan inti sangat bergantung pada metode yang dipergunakan dalam proses belajar membelajarkan. Walaupun metode ini bermacammacam, dosen hendaknya dapat merangsang aktivitas siswa dalam belajar. Metode membelajarkan merupakan bagian perangkat alat dan cara dalam pelaksanaan kegiatan belajar membelajarkan untuk mencapai tujuan-tujuan belajar.

Berikut ini adalah teknik sistem penyajian (metode membelajarkan) yang dapat digunakan oleh dosen agar dapat menyajikan bahan pelajaran dengan metode yang tepat untuk materi tertentu ataupun dapat membuat variasi dalam menyajikan bahan tersebut, yaitu metode ceramah, metodenya jawab, metode diskusi, metode kerja kelompok, metode simulasi, dan metode demonstrasi.
Agar pelaksanaan proses belajar membelajarkan dapat berjalan baik maka dosen harus menguasai beberapa keterampilan dasar yang diutamakan sebagai berikut.

1) Keterampilan memberi penguatan.

2) Keterampilan bertanya.

3) Keterampilan menggunakan variasi.

4) Keterampilan menjelaskan.

5) Keterampilan membuka dan menutup pelajaran.

6) Keterampilan membelajarkan kelompok kecil dan perorangan.

7) Keterampilan mengelola kelas.

8) Keterampilan membimbing diskusi.

Kegiatan penutup meliputi kegiatan menyimpulkan materi pelajaran; tes formatif, sebagai umpan balik keberhasilan guru dalam membelajarkan; tindak lanjut (follow up) dari bahan yang telah dipelajari.

c. Penilaian hasil pembelajaran

Setiap proses pembelajaran selalu ingin mengetahui umpan balik dari semua materi yang disajikan dosen. Evaluasi pencapaian belajar mahasiswa adalah salah satu kegiatan yang merupakan kewajiban bagi dosen. Dikatakan kewajiban karena setiap pengajar pada akhirnya harus dapat memberikan informasi kepada lembaganya atau kepada mahasiswa itu sendiri. Bagaimana dan sejauh mana materi dan keterampilan yang diberikan telah dikuasai mahasiswa.

Kegiatan evaluasi yang dilakukan oleh dosen mempunyai tujuan memperoleh kepastian mengenai keberhasilan belajar anak didik dan memberikan masukan pada dosen mengenai pembelajaran yang telah berlangsung. Dalam hubungannya dengan pembelajaran, Grondlund (1974) merumuskan pengertian tentang evaluasi adalah suatu proses yang sistematis untuk menentukan atau membuat keputusan sampai sejauh mana tujuan-tujuan pembelajaran telah dicapai oleh siswa.

Ada beberapa prinsip dasar yang perlu diperhatikan dalam menyusun evaluasi hasil belajar agar dapat mengukur kemampuan dan atau keterampilan mahasiswa menyelesaikan suatu unit pembelajaran tertentu, yaitu sebagai berikut.

1) Evaluasi hendaknya dapat mengukur secara jelas hasil belajar yang telah ditetapkan sesuai dengan tujuan pembelajaran.

2) Mengukur sampel yang representatif dari hasil belajar dan bahan pelajaran yang telah diajarkan. 
3) Mencakup bermacam-macam bentuk soal yang benar-benar cocok untuk mengukur hasil belajar yang diinginkan sesuai dengan tujuan.

4) Didesain sesuai dengan kegunaannya untuk memperoleh hasil yang diinginkan.

5) Dibuat seandal (reliabel) mungkin sehingga mudah diinterpretasikan dengan baik.

6) Digunakan untuk memperbaiki cara belajar siswa dan cara membelajarkan guru.

Menurut Sudjana (1999), pada umumnya ada tiga sasaran pokok evaluasi, yaitu (1) segi tingkah laku, (2) segi isi pendidikan, dan (3) segi yang menyangkut proses belajar membelajarkan itu sendiri. Setelah melakukan langkah-langkah seperti di atas, dapat dikatakan bahwa pengolahan skor tes hasil belajar sudah mencapai kesimpulan akhir, yaitu hasil penilaian dalam bentuk angka.

\section{METODOLOGI PENELITIAN}

\section{Tempat dan Waktu penelitian}

Penelitian ini dilaksanakan di lingkungan UNJ selama delapan bulan, yaitu bulan April sampai November 2007. Waktu penelitian digunakan untuk melakukan langkah-langkah penelitian yang dimulai dengan mengajukan proposal kepada FIP UNJ.

\section{Metode Penelitian}

Penelitian ini menggunakan metode deskriptif bentuk survei sedangkan analisis datanya menggunakan statistika sederhana. Pengumpulan data digunakan angket tertutup dan terbuka yang disebarkan kepada mahasiswa UNJ yang mengikuti perkuliahan MKDK pada semester 086.

\section{Desain Penelitian}

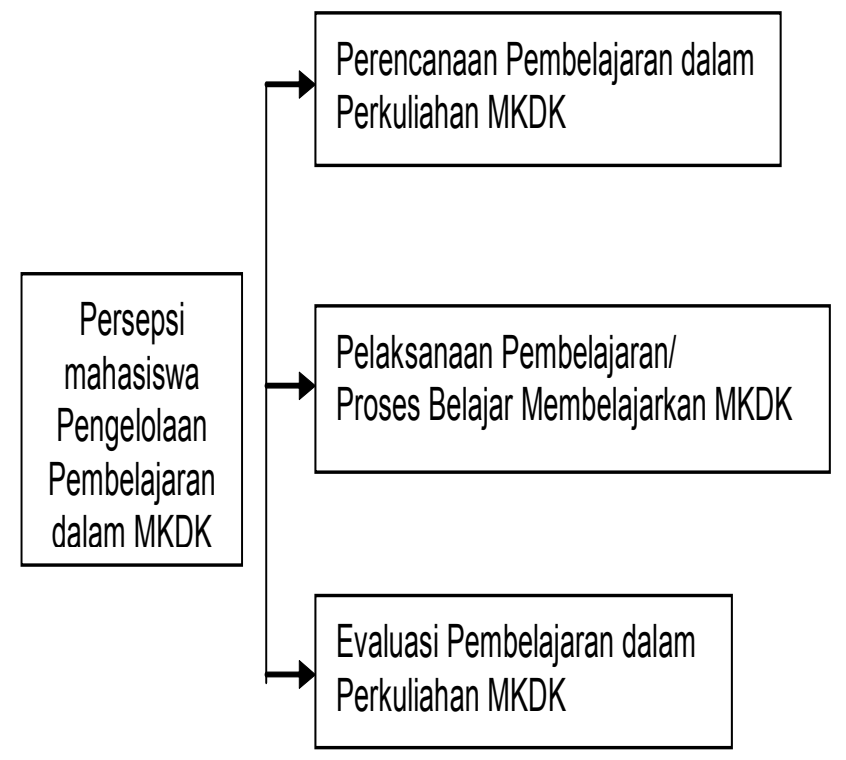

Gambar 1. Desain penelitian

\section{Populasi dan Sampel Penelitian}

Populasi penelitian ini adalah semua mahasiswa peserta kuliah MKDK pada semester 086 di lingkungan FIP UNJ, yaitu dalam empat mata kuliah Pengantar Ilmu Pendidikan, Teori Belajar dan Pembelajaran, Psikologi Perkembangan, serta Profesi Kependidikan. Adapun yang dijadikan sampel dalam penelitian ini adalah 80 orang mahasiswa UNJ yang telah dan sedang mengikuti perkuliahan MKDK pada semester 086 Januari-Juli 2007. Teknik pengambilan sampel adalah teknik acak sederhana sesuai kelompok mata kuliah yang ada dalam MKDK.

\section{Instrumen Penelitian}

Instrumen penelitian ini menggunakan angket atau daftar pertanyaan terbuka dan tertutup, untuk mengukur tiga masalah penelitian: (1) sistem perencanaan pembelajaran MKDK, (2) sistem pelaksanaan pembelajaran MKDK, dan (3) sistem evaluasi pembelajaran MKDK. Pengumpulan data mengenai faktor-faktor penghambat dan pendukung pengelolaan pembelajaran menggunakan pertanyaan terbuka yang diisi oleh mahasiswa UNJ peserta kuliah MKDK.

\section{Teknik Pengumpulan Data}

Teknik pengumpulan data dilakukan dengan cara memberikan instrumen pada responden atau sampel. Responden dalam penelitian ini adalah 20 mahasiswa yang diambil dari setiap sampel dosen sebanyak empat orang, jadi jumlah responden sebanyak $20 \times 4=80$ orang mahasiswa. Peneliti memberikan pengarahan pada responden bagaimana cara mengisi instrumen dan peneliti memberikan waktu satu hari untuk mengisinya. Peneliti menegaskan bahwa setiap responden diharapkan mengisi instrumen secara objektif agar diperoleh hasil penelitian yang objektif pula.

\section{Teknik Analisis Data}

Penelitian ini menggunakan teknik analisis statistik deskriptif. Teknik statistik deskriptif dimaksudkan untuk menggambarkan karakteristik tujuan-tujuan penelitian dalam bentuk persentase dan skema.

Rumus yang digunakan:

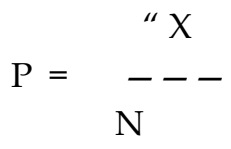

$\mathrm{P}=$ persentasekarakteristik yang dideskripsikan

$\mathrm{X}=$ frekuensi karakteristik yang berasal dari data pengamatan

$\mathrm{N}$ = jumlah anggota sampel

Perspektif Ilmu Pendidikan - Vol. 17 Th. IX April 2008 


\section{HASIL PENELITIAN}

1. Persepsi mahasiswa tentang pengetahuan dosen dalam menyusun perencanaan pembelajaran yang telah dilakukan dosen MKDK pada semester 086, secara umum sudah cukup. Hal ini disebabkan oleh sebagian besar dosen MKDK sudah membuat persiapan pembelajaran dalam bentuk silabus dan silabus yang dibuat dosen pada dasarnya memiliki sistematika yang sama dengan yang dibuat oleh tim MKDK. Perencanaan perkuliahan dalam bentuk Satuan Acara Perkuliahan (SAP) atau rencana kuliah per tatap muka sehingga perlu adanya pembinaan pada dosen MKDK untuk mampu membuat persiapan kuliah yang benar atau berstandar. Di samping itu, mahasiswa menginginkan adanya jadwal yang tidak diubah-ubah agar dosen tidak terlambat memberi kuliah dan mahasiswa tidak mengalami kesulitan dengan jadwal tersebut.

2. Persepsi mahasiswa tentang kemampuan dosen dalam pelaksanaan pembelajaran atau perkuliahan MKDK secara umum cukup walaupun masih harus ditingkatkan. Hal ini dapat terlihat sebagai berikut. a. Setiap dosen mengacu pada jadwal akademik terpadu yang disusun oleh PR I UNJ. Pada kenyataannya masih terdapat dosen tidak memberikan kuliah tepat sesuai dengan jadwal terpadu tersebut. Cukup banyak dosen yang tidak tepat waktu. Keterlambatan ini sangat bervariasi paling banyak dua pertemuan atau satu minggu terlambatnya dari jadwal yang ada. Alasan keterlambatan dosen memulai perkuliahan antara lain karena menggantikan dosen yang lain membelajarkan, menerima daftar peserta kuliah terlambat, jadwal perkuliahan bentrok, dan mahasiswa terlambat hadir sedangkan alasan yang paling banyak ialah daftar mahasiswa terlambat diterima dosen.

b. Ketidakhadiran mahasiswa di awal perkuliahan juga masih ditemukan maka perlu dicari penyebabnya. Pada awal perkuliahan dosen MKDK secara umum sudah membahas silabus sebagai kontrak perkuliahan selama satu semester. Jika dosen tidak hadir ada pemberitahuan kepada mahasiswa.

c. Pada tahap pendahuluan dosen MKDK sudah melakukan berbagai kegiatan seperti mengulang materi, mengecek kehadiran kuliah, dan memberikan tugas pada mahasiswa.

d. Dalam pelaksanaan perkuliahan penggunaan media atau alat pembelajaran masih sangat minim, belum bervariasi, dan didominasi hanya oleh penggunaan $O H P$. Dalam hal ini perlu adanya penambahan media belajar yang lebih baik kualitasnya dan bervariasi.

e. Metode perkuliahan yang digunakan dosen MKDK cenderung konvensional terbatas hanya ceramah, tugas, dan tanya jawab mendominasi sedangkan penggunaan metode yang modern kurang dilakukan.

f. Pada tahap menutup perkuliahan dosen sudah berhasil melakukan berbagai teknik menutup perkuliahan, seperti merangkum dan memberikan tugas mandiri atau kelompok. Walaupun belum semua dosen melakukannya secara rutin.

3. Persepsi mahasiswa tentang kemampuan dosen dalam pelaksanaan evaluasi pembelajaran secara umum sudah cukup, tetapi masih perlu ditingkatkan. Hal ini dikarenakan dari data yang diperoleh tampak bahwa dosen MKDK sudah melakukan evaluasi jenis Ujian Tengah Semester (UTS), Ujian Akhir Semester (UAS), dan sedikit ujian formatif. Tetapi masih ada juga dosen yang tidak melakukan UTS, UAS, dan tes formatif. Bentuk UTS yang paling banyak digunakan adalah bentuk uraian sebanyak $50 \%$ sedangkan bentuk objektif dan uraian juga digunakan. Hal ini tampak bahwa dosen belum mempunyai pedoman yang sama tentang bentuk dan jumlah soal UTS. Sifat UTS yang digunakan responden cukup seimbang antara ujian open book dan close book ada juga yang menggunakan ujian take home. Jadi, sifat UTS yang digunakan juga tidak sama di antara dosen MKDK. UAS yang dilakukan responden sebagian besar menggunakan bentuk ujian tes uraian sedangkan sisanya menggunakan bentuk ujian objektif dan campuran. Hal ini menunjukkan dosen cenderung hanya menggunakan bentuk tes uraian dengan alasan mudah dan cepat menyusunnya sehingga hanya separuh materi saja yang dapat diujikan. Padahal dilihat dari prinsip penilaian hasil belajar, jenis tes sumatif atau UAS harus bisa menguji materi yang banyak secara komprehensif untuk setiap mata kuliah. Nilai akhir mata kuliah selain diambil dari nilai UTS dan UAS-nya mengambil nilai juga dari unsur lain seperti nilai tugas makalah, kehadiran, keaktifan dalam perkuliahan, dan tugas-tugas terstruktur. Walaupun dalam kenyataan masih juga ada separuh responden yang tidak menggunakan unsur-unsur penilaian semua itu. Jika ternyata hasil-hasil penilaian dari UTS, UAS, dan tugastugas responden kurang nilainya dosen 
memberikan kesempatan untuk memperbaiki atau mengulang ujian. Saran-saran yang disampaikan responden kepada koordinator MKDK dalam pelaksanaan evaluasi cukup banyak yaitu perlu adanya tes terstandar bagi semua dosen, perlu ada media atau alat evaluasi yang baik, perlu adanya transpor pengawas ujian dan koreksi hasil ujian, dan adanya penggantian fotocopy soal atau lembar jawaban jika soal tidak disiapkan koodinator MKDK.

4. Dilihat dari tiga indikator persepsi mahasiswa tentang pengelolaan pembelajaran MKDK pada semester 086, secara umum cukup efektif karena rata-rata lebih dari $60 \%$ sudah melaksanakan kegiatan-kegiatan pembelajaran mulai dari perencanaan, pelaksanaan, dan penilaian pembelajaran MKDK. Walaupun demikian, masih perlu adanya peningkatan agar bisa lebih baik.

5. Menurut hasil penelitian sebelumnya ternyata perkuliahan MKDK dari semester ke semester tidak ada perubahan yang berarti. Perubahan yang ada hanya terdapat pada penggunaan media seperti $L C D, T V$, dan film-film yang sudah tersedia di koordinator MKDK UNJ.

\section{KESIMPULAN}

\section{Kesimpulan}

Persepsi mahasiswa tentang pengelolaan pembelajaran yang meliputi kegiatan perencanaan, pelaksanaan, dan evaluasi pembelajaran oleh dosen dalam MKDK pada semester 086 tahun 2006/2007 UNJ secara umum sudah cukup, walaupun masih perlu ditingkatkan.

\section{Implikasi}

Berdasarkan kesimpulan hasil penelitian yang telah diuraikan di atas maka dapat dijelaskan implikasi hasil penelitian ini sebagai berikut.

1. Perlu adanya peningkatan pemahaman pada para dosen tentang pentingnya membuat perencanaan pembelajaran sebelum memberi kuliah baik bentuknya silabus maupun SAP. Hal ini disebabkan masih ada beberapa responden yang mengatakan tidak membuat silabus dan SAP. Silabus yang sudah disusun tim dosen MKDK perlu dilakukan revisi karena banyak yang sudah tidak up to date lagi dan belum mengacu pada kurikulum berbasis kompetensi sesuai dengan kurikulum 2004.

2. Perlu adanya peningkatan kemampuan dosen, hal ini disebabkan masih banyak ditemukan dosen yang belum melaksanakan perkuliahan dengan bantuan media pembelajaran dan metode yang modern dan bervariasi. Hal ini disebabkan ketersediaan media elektronik seperti $O H P, \mathrm{LCD}$, dan video masih sangat kurang. Metode pembelajaran yang terbaru masih banyak belum dilakukan, dosen MKDK hanya terpaku pada metode pembelajaran yang tradisional seperti ceramah, tanya jawab, dan tugas. Untuk itu, dosen perlu diberikan pelatihan agar lebih mampu menggunakan metode pembelajaran yang bervariasi dan modern.

3. Pengetahuan dosen dalam menyusun perencanaan pembelajaran yang telah dilakukan dosen MKDK masih perlu ditingkatkan kualitas dan kuantitasnya. Hal ini disebabkan masih belum adanya standar evaluasi MKDK yang jelas sehingga waktu pelaksanaan ujian, jenis, bentuk, dan sifat ujian baik UTS maupun UAS masih sangat tergantung pada kreativitas dari dosen yang bersangkutan atau tidak adanya keseragaman di antara para dosen MKDK yang ada. Hal ini dapat berimplikasi sulitnya mencari standar kompetensi mahasiswa program kependidikan yang mengikuti MKDK ini. Untuk mengatasi hal ini maka koordinator MKDK perlu menyusun ketentuan tentang bentuk jenis, jumlah butir soal dan sifat UTS serta UAS, jadwal ujian MKDK yang terpola, dan kemudian disosialisasikan kepada seluruh dosen. Selain itu, pelaksanaan ujian perlu ada pengawasan yang jelas dari koordinator MKDK sehingga dosen tidak sewenang-wenang melaksanakan ujian. Jika memungkinkan dibentuk panitia ujian MKDK.

\section{Saran}

Adapun beberapa saran untuk perbaikan efektivitas manajemen pembelajaran MKDK di UNJ dapat diuraikan sebagai berikut.

1. Dosen MKDK

a. Hendaknya sebelum memberikan perkuliahan dosen menyiapkan perencanaan perkuliahan sebagai pedoman kuliah dalam bentuk silabus dan SAP atau hand out setiap tatap muka. Silabus dan SAP yang sudah disiapkan hendaknya disosialisasikan kepada mahasiswa.

b. Dalam pelaksanaan perkuliahan usahakan langkah-langkah kegiatan perkuliahan dilakukan mulai tahap pendahuluan, penyajian, dan penutup.

c. Penggunaan media dan metode yang bervariasi dan modern hendaknya digunakan dengan meminta bantuan kepada koodinator MKDK. 
d. Evaluasi hasil pembelajaran oleh dosen hendaknya dilakukan secara terjadwal dan serempak.

2. Bagi koordinator MKDK

a. Hendaknya membantu dosen-dosen merevisi dan menyiapkan silabus atau SAP agar perkuliahan lebih terencana.

b. Agar pelaksanaan pembelajaran MKDK lebih berkualitas hendaknya koordinator MKDK dapat mengusahakan untuk melengkapi media dan buku-buku yang berhubungan dengan perkuliahan MKDK bagi dosen dan mahasiswa.

c. Hendaknya mengelola pelaksanaan UTS dan UAS agar setiap dosen MKDK melakukan ujian secara bersama-sama.

d. Hendaknya membentuk tim revisi silabus dan soal-soal ujian secara bersama-sama.

3. Bagi pimpinan UNJ

a. Perlu adanya penambahan dana rutin untuk koordinator MKDK sehingga dapat ditingkatkan pelayanan perkuliahan pada dosen dan mahasiswa, seperti pengadaan buku-buku sumber, media belajar, dan ruang perkuliahan yang memadai.

b. Hendaknya antara unit-unit yang terkait dengan perkuliahan MKDK lebih ditingkatkan kerja samanya tingkat universitas melalui PR I UNJ.

\section{DAFTAR PUSTAKA}

Gagne, R. M. \& Briggs, L.J. (1979). Priciples of instructional design. Florida University: Halt.

Groundlund, N. (1974). Improving marking and reporting in classroom instruction. Macmillan Publishing Co, Inc.

Gunawan, J. (1989). Komunikasi dalam organisasi. Jakarta: Rineka Cipta.

Johnson, R.A., Kast, F.E. \& Rosenzweig, J.E. (1973). The theory and management of systems. New York: McGraw-Hill.
Julitriasa, D. \& Suprihanto, J. (1998). Pengelolaan umum sebuah pengantar. Yogyakarta: BPFE.

Keputusan menteri (Kepmen) No. 232/U/2000 Tentang Pedoman Penyusunan Kurikulum Pendidikan Tinggi dan Penilaian Hasil Belajar Mahasiswa. (2000). Jakarta: Depdiknas.

Keputusan Presiden (Keppres) 093/1999 Tanggal 4 Agustus Tahun 1999. (1999). (http:// www.unj.ac.id/idx.php?name=Sections\&op=viewarticle\&artid=33)

Oberg, K. (1960). Culture shock and the problem of adjustment in new cultural environments. In: Weaver, G. R. (Ed.). (1998). Culture, communication and conflict. readings in intercultural relations. Needham Heights, MA: Simon \& Schuster Publishing.

Rahmat, J. (1999). Psikologi komunikasi. Bandung: Rosda Karya.

Rivai, V. (2004). Kepemimpinan dan perilaku organisasi. Jakarta: Raja Grafindo.

Roestiyah, N.K. (1994). Masalah pengajaran: Sebagai suatu sistem. Jakarta: Rineka Cipta.

Sudjana, N. (1999). Pengantar statistik. Bandung: Tarsito.

Sunarya, E. (1996). Berpikir kesisteman. Jakarta: Rineka Cipta.

Terry, G.R. \& Rue, L.W. (1985). Dasar-dasar manajemen (alih bahasa oleh G.A. Ticoalu). Jakarta: Bina aksara.

Thoha, M. (2003). Perilaku organisasi konsep dasar dan aplikasinya. Jakarta: Raja Grafindo Persada.

Universitas Negeri Jakarta. (2004). Pedoman Kegiatan Akademik 2003/2004. Jakarta: UNJ.

Walgito, B. (2002). Pengantar psikolog umum. Yogyakarta: Andi.

\section{KETERANGAN PENULIS}

Dra. Neti Karnati, M.Pd., dilahirkan di Sumedang, Februari 1962. Saat ini menjadi dosen Jurusan Manajemen Pendidikan FIP UNJ. Pengalaman kerja selain di Perguruan Tinggi Negeri adalah mengajar di seperti Akademi Kebidanan Rumah Sakit Cipto Mangunkusumo dan Harapan Kita. 